AZIZOV I.V. ${ }^{\bowtie}$, GASYMOVA F.I., IBRAGIMOVA U.F., TAGIYEVA K.R., ABDULLAYEVA A.B. Institute of Molecular Biology and Biotechnologies of the National Academy of Sciences of Azerbaijan, Azerbaijan, AZ1073, Baku, Izzat Nabiyev str., 11, e-mail: Ibrahim.azizov47@ gmail.com

× fazilay@yahoo.com, +99450 6855093

\title{
THE EFFECT OF BLUE AND RED LIGHT ON PHYSIOLOGICAL AND BIOCHEMICAL CHARACTERISTICS OF WHEAT PLANTS
}

Aim. The effect of blue and red light on the activity of catalase and ascorbate peroxidase, the content of proteins and soluble carbohydrates in the leaves of wheat varieties under the action of sodium chloride were investigated. Methods. The objects of research were bread wheat Saratovskaya-29 (Triticum aestivum L.) and durum wheat Barakatli-95 (Triticum durum Desf.). Plants were grown in laboratory conditions in an aqueous medium using a Knoop nutrient medium. Experimental plants were coated with transparent films transmitting light at wavelengths of 420-480 nm (blue light) and 640$680 \mathrm{~nm}$ (red light). During the growing season, samples of fully formed leaves were taken for physiological and biochemical studies every week at 11 a.m. Results. Under the action of sodium chloride, the accumulation of hydrogen peroxide in white light was higher than in blue and red light (table). Low catalase activity was also observed in blue and red light under the influence of sodium chloride in both varieties. In bread wheat variety Saratovskaya -29 level of hydrogen peroxide, the activity of catalase and ascorbate peroxidase enzymes was lower than that of the Barakatli-95 durum wheat variety. Conclusions. Blue light stimulated the synthesis of proteins, while red light stimulated the synthesis of carbohydrates. Blue and red light prevented the formation of $\mathrm{H}_{2} \mathrm{O}_{2}$ under the influence of $\mathrm{NaCl}$.

Keywords: blue light, red light, catalase, ascorbate peroxidase, proteins, carbohydrates.

One of the essential factors necessary for the growth, development, and productivity of plants is the intensity and spectral composition of light. In conditions of insufficient provision of sunlight, the process of photosynthesis disrupted, growth, development, yield, and plant resistance reduced. There are numerous works in the literature on the study of the intensity and spectral composition of light on growth and development, photosynthesis, and plant productivity $[1,3,8,9,10-12,13,16]$. Light also acts as an effective regulator that controls the mor- phogenesis of plants during the individual development of plants [15]. The spectral composition of light affects the growth and development of wheat seedlings. Under optimal growing conditions in red light, there is a tendency to stimulate the growth of both the aerial part and the roots, compared with seedlings grown in white and blue light. More carbohydrates synthesized in the leaves under red light than under blue light and, on the contrary, more proteins synthesized under blue light than under red light [3-7].

The study of the effect of red light on the synthesis of proteins and carbohydrates in plant leaves is of both theoretical and practical value. Our research aimed to study the blue and red light physiological and biochemical characteristics of wheat genotypes.

\section{Material and methods}

Two varieties of winter wheat Saratovskaya29 (Triticum aestivum L.) and Barakatli-95 (Triticum durum Desf.) were used in the work. Plants were grown in laboratory conditions in an aqueous medium using a Knoop nutrient medium. Experimental plants were coated with transparent films transmitting light at wavelengths of $420-480 \mathrm{~nm}$ (blue light) and 640-680 nm. (Red light). During the growing season, samples of fully formed leaves were taken for physiological and biochemical studies every week at 11 a.m. Photosynthetic pigments were determined by homogenizing the leaves on $96 \%$ ethanol, with further centrifugation at $200 \mathrm{~g}$, on a spectrophotometer at wavelengths of 665,649 , and $440.5 \mathrm{~nm}$, using the coefficient Wintermans, De Mots, 1965 [2]. The content of soluble sugars was determined by the accelerated bichromate method, at a wavelength of $630-570 \mathrm{~nm}$ [2]. The protein content was determined on a SP 2000 spectrophotometer at a wavelength of 230 and $260 \mathrm{~nm}$, according to the method of Kalb, Bernlohr [2]. The determination of hydrogen peroxide was carried out using a method based on the formation of a colored

\footnotetext{
${ }^{\circ}$ AZIZOV I.V., GASYMOVA F.I., IBRAGIMOVA U.F., TAGIYEVA K.R., ABDULLAYEVA A.B.
} 
compound - a titanium peroxide complex [14]. The concentration of $\mathrm{H}_{2} \mathrm{O}_{2}$ was calculated from the standard calibration curve of the level of hydrogen peroxide and expressed in $\mathrm{mmol} / \mathrm{g}$ wet weight. Catalase activity (Cat) was measured by the rate of $\mathrm{H}_{2} \mathrm{O}_{2}$ degradation according to the procedure [14]. A drop in optical density was recorded for 1 minute after adding a solution of $100 \mu \mathrm{l}$ of $0.1 \mathrm{M} \mathrm{H}_{2} \mathrm{O}_{2}$ to the enzyme extract and the enzyme activity expressed in mmol of decomposed peroxide / $\mathrm{g}$ wet weight per minute. The activity of ascorbate peroxidase (APO) was determined at $\mathrm{pH} 7.0$ by the decrease in light absorption at $290 \mathrm{~nm}$. The protein content was analyzed according to the Bradford method, using BSA as a standard [2].

The experiments were performed in triplicate biological repetition and each reproduced independently 2-3 times. The figures and tables show the average values and their standard deviations $(\mathrm{M} \pm$ $\sigma)$. The significance of differences between the options was evaluated using t-student test.

\section{Results and discussion}

The influence of blue and red light on physiological and biochemical parameters was unidirectional, but there were varietal differences. In blue light, plants grew more intensely than in red light. Under the influence of sodium chloride, the accumulation of hydrogen peroxide in white light was higher than in blue and red light (table).

Low catalase activity was also observed in blue and red light under the action of sodium chloride in both varieties. In bread wheat variety Saratovskaya-29 level of hydrogen peroxide, the activity of catalase and ascorbate peroxidase enzymes was lower than that of the Barakatli-95 durum wheat variety. The accumulation of carbohydrates and proteins was different: red light contributed to the synthesis of carbohydrates, and blue light contributed to the synthesis of proteins. The rapid growth of plants and the low content of hydrogen peroxide under the influence of salt in blue light can be explained by the effect of blue light on the metabolic processes of the cell.

There is evidence that during drought and salinization, blue light contributes to synthesis of low molecular weight compounds that increase the water retention capacity of the cell $[17,18]$. In this work, it has also been shown that under the salinization condition, the seedling growth rate decreased by $20 \%$ in blue light, while in red light, it fell by $50 \%$.

Many authors have noted the regulatory effect of blue light on plant metabolism through cryptochromes. Blue light photoreceptors are flavins and carotenoids. The yellow pigment riboflavin, a receptor of blue, is the near-ultraviolet light called cryptochrome. It is present in all plants. In the ultraviolet part of the spectrum (320-390 nm), another receptor system is probably working, including pyrazine-pyrimidine derivatives or pterins. Receptors undergo redox transformations, quickly transferring electrons to other acceptors. Plant phototropism is determined by the receptor complex of the stem apex, which includes cryptochrome and carotenoids. Blue light receptors were found in the cells of all tissues, localized in the plasmalemma and other membranes. The photomorphogenic effect of red light on a plant was carried out through phytochromes F660 and F730.

Table. The effect of blue and red light on the physiological and biochemical parameters of wheat leaves*

\begin{tabular}{|c|c|c|c|c|c|c|}
\hline Wheat variety & $\begin{array}{c}\text { Light } \\
\text { spectrum }\end{array}$ & $\begin{array}{c}\mathrm{H}_{2} \mathrm{O}_{2,} \\
\mathrm{mkmol} / \mathrm{g}\end{array}$ & $\begin{array}{c}\text { Carbohydrates } \\
\mathrm{mg} / \mathrm{g}\end{array}$ & $\begin{array}{c}\text { CAT, } \mu \mathrm{mol} / \\
\text { mg protein }\end{array}$ & $\begin{array}{c}\text { APO, } \mu \mathrm{mol} / \\
\mathrm{mg} \text { protein }\end{array}$ & $\begin{array}{c}\text { Protein, } \\
\mathrm{mkg} / \mathrm{ml}\end{array}$ \\
\hline \multirow{3}{*}{$\begin{array}{c}\text { Saratovskaya-29 } \\
\text { Control }\end{array}$} & White & $1,1 \pm 0,08$ & $40 \pm 2,3$ & $0,6 \pm 0,02$ & $1,0 \pm 0,08$ & $41 \pm 2,2$ \\
\cline { 2 - 7 } & Red & $0,9 \pm 0,07$ & $34 \pm 1,5$ & $0,5 \pm 0,01$ & $1,3 \pm 0,09$ & $37 \pm 1,4$ \\
\cline { 2 - 7 } & Blue & $1,6 \pm 0,09$ & $30 \pm 1,3$ & $0,4 \pm 0,03$ & $0,2 \pm 0,07$ & $43 \pm 2,3$ \\
\hline \multirow{2}{*}{$\begin{array}{c}\text { Saratovskaya-29 } \\
100 \text { mmol NaCl }\end{array}$} & White & $2,8 \pm 0,09$ & $50 \pm 2.2$ & $1,8 \pm 0,09$ & $8,1 \pm 0,09$ & $46 \pm 2,2$ \\
\cline { 2 - 7 } & Red & $1,9 \pm 0,06$ & $60 \pm 3,4$ & $0,7 \pm 0,05$ & $2,2 \pm 0,07$ & $42 \pm 1,5$ \\
\cline { 2 - 7 } & Blue & $1,6 \pm 0,05$ & $40 \pm 4,5$ & $0,6 \pm 0,04$ & $1,3 \pm 0,04$ & $52 \pm 3,3$ \\
\hline \multirow{2}{*}{$\begin{array}{c}\text { Barakatli 95 } \\
\text { Control }\end{array}$} & White & $1,8 \pm 0,07$ & $32 \pm 5,1$ & $1,8 \pm 0,07$ & $0,6 \pm 0,03$ & $100 \pm 3,6$ \\
\cline { 2 - 7 } & Red & $0,9 \pm 0,04$ & $30 \pm 2,4$ & $1,0 \pm 0,06$ & $0,8 \pm 0,02$ & $95 \pm 1,5$ \\
\cline { 2 - 7 } Barakatli 95 & Blue & $1,7 \pm 0,05$ & $24 \pm 3,3$ & $1,7 \pm 0,08$ & $0,5 \pm 0,06$ & $100 \pm 2,7$ \\
\cline { 2 - 7 } 100 mmol NaCl & White & $3,4 \pm 0,04$ & $60 \pm 2,6$ & $2,2 \pm 0,04$ & $0,6 \pm 0,5$ & $108 \pm 3,5$ \\
\cline { 2 - 7 } & Red & $2,9 \pm 0,09$ & $65 \pm 1,7$ & $2,2 \pm 0,09$ & $0,8 \pm 0,07$ & $100 \pm 2,4$ \\
\cline { 2 - 7 } & Blue & $3,0 \pm 0,06$ & $50 \pm 2,8$ & $1,8 \pm 0,08$ & $0,5 \pm 0,04$ & $110 \pm 1,5$ \\
\hline
\end{tabular}

Notes: *Each value represents the mean $\pm \mathrm{SD}$ (standard deviation) for the mean $\mathrm{n}=3$ independent experiments $\mathrm{p}=0.05$. 


\section{Conclusions}

1. Blue and red light prevent the formation of hydrogen peroxide in wheat cells under the action of sodium chloride.

2. Blue light stimulates synthesis of proteins, and red light stimulates synthesis of carbohydrates in wheat cells.
This work is supported by Azerbaijan National Academy of Sciences under the Azerbaijan-Belarus project: "Phytochrome regulation of photochemical processes as a factor in increasing the stress tolerance of cultivated plants."

\section{References}

1. Bell L.H. The quality of light as a factor regulating the energy of photosynthesis. In: Theoretical foundations of photosynthetic productivity. M.: Science, 1972. S. 50-62. [in Russian] / Белл Л.Н. Качество света как фактор, регулирующий энергетику фотосинтеза. В сб. Теоретические основы фотосинтетической продуктивности. М.: Наука, 1972. С. $50-62$.

2. Large workshop "Biochemistry". 2012. 108 s. [in Russian] / Большой практикум «Биохимия». 2012. 108 c.

3. Bradford M.M. Rapid and Sensitive Method for the Quantitation of Microgram Quantities of Protein Utilizing the Principle of Protein-Dye Binding. Anal. Biochem. 1976. Vol. 72. P. 248-254.

4. Voskresenskaya N.P. Photosynthesis and spectral composition of light. M.: Nauka, 1965. 312 p. [in Russian] / Воскресенская Н.П. Фотосинтез и спектральный состав света. М.: Наука, 1965. 312 с.

5. Voskresenskaya N.P., Nechaeva V.P. The effect of blue, red and green light on the content of protein, nucleic acids, and chlorophyll in young barley plants. Plant physiol. 1967. No. 2, Issue. 14. Р. 299-307. [in Russian] /Воскресенская Н.П., Нечаева B.П. Действие синего, красного и зелёного света на содержание белка, нуклеиновых кислот и хлорофилла в молодых растениях ячменя. Физиол. растений. 1967, № 2, Вып. 14. С. 299-307.

6. Voskresenskaya N.P., Nechaeva E.P., Vlasova M.P., Nichiporovich A.A. The value of blue light and kinetin for the restoration of the photosynthetic apparatus of aging barley leaves. Plant physiol. 1968. Vol. 15, No. 5. P. 890-897. [in Russian] / Bоскресенская Н.П., Нечаева Е.П., Власова М.П., Ничипорович А.А. Значение синего света и кинетина для восстановления фотосинтетического аппарата стареющих листьев ячменя. Физиол. растений. 1968. Т. 15, Вып. 5. С. 890-897.

7. Voskresenskaya N.P., Omarova I.S., Krylov Yu.V. The effect of long and short-term effects of blue light on the photosynthesis of pea plants. DAS SSSR. 1968. Vol. 182, No. 6. Р. 1443-1449. [in Russian] / Воскресенская Н.П., Омарова И.С., Крылов Ю.В. Влияние длительного и кратковременного действия синего света на фотосинтез растений гороха. ДАН СССР. 1968. T. 182, № 6. C. 1443-1449.

8. Voskresenskaya N.P. The regulatory role of blue light in the formation of photosynthetic apparatus activity. Physiol. and biochemistry of cultivated plants. 1976. Vol. 8, No. 4. Р. 339-348. [in Russian] / Воскресенская Н.П. Регуляторная роль синего света в формировании активности фотосинтетического аппарата. Физиол. и биохимия культурных растений. 1976. Т. 8, Вып. 4. С. 339-348.

9. Gold V.M., Gaevsky N.A., Botkina T.I., Grigoryev Yu.S. The activity of photochemical reactions in aspidistra in blue and red light. Plant physiol. 1973. Vol. 20, No. 3. Р. 539-543. [in Russian] / Гольд В.М., Гаевский Н.А., Боткина Т.И., Григорьев Ю.С. Активность фотохимических реакций у аспидистры на синем и красном свету. Физиол. растений. 1973. Т. 20, № 3. C. 539-543.

10. Karnachuk R.A. Regulatory effect of green light on the growth and photosynthesis of leaves. Plant. physiol. 1987. .Vol. 34, № 3. P. 765-773. [in Russian] / Карначук Р.А. Регуляторное влияние зеленого света на рост и фотосинтез листьев. Физиол. растений. 1987. Т. 34, № 3. С. 765-773.

11. Karnachuk R.A., Golovatskaya I.F. Hormonal status, growth, and photosynthesis of plants grown in the light of various spectral compositions. Plant physiol. 1998. T. 45, No. 6. Р. 925-934. [in Russian] / Карначук Р.А., Головацкая И.Ф. Гормональный статус, рост и фотосинтез растений, выращенных на свету различного спектрального состава. Физиол. растений. 1998. T. 45, № 6. C. 925-934.

12. Krasnovsky A.A. Plant cell photoreceptors and paths of light regulation. Photoregulation of metabolism and plant morphogenesis. M: Science, 1975. P. 5-15. [in Russian] / Красновский А.А. Фоторецепторы растительной клетки и пути светового регулирования. Фоторегуляция метаболизма и морфогенеза растений. М: Наука, 1975. С. 5-15.

13. Kuznetsov E.D., Ivanova Z.P., Shakhov A.A. Phytochrome-dependent photoregulation, its mechanisms and significance for light control of plants. Problems of plant phyto-energetics. Alma-Ata, 1978. Is. 5 P. 21-42. [in Russian] / Кузнецов Е.Д., Иванова 3.П., Шахов А.А. Фитохромзависимая фоторегуляция, ее механизмы и значение для светового управления растениями. Проблемы фто-энергетики растений. Алма-Ата, 1978. Вып. 5. С. 21-42.

14. Kumar G., Knowles N.R. Changes in Lipid Peroxidation and Lipolytic and Free-Radical Scavenging Enzyme Activities during Aging and Sprouting of Potato (Solanum tuberosum) Seed-Tubers. Plant Physiol. 1993. Vol. 102 (1). P. 115-124.

15. Petrov V.E., Loseva N.L. Energy of an assimilating cell and photosynthesis. Energy aspects of plant resistance. Kazan: Kazan Publishing House, University, 1986. Р. 5-76. [in Russian] / Петоров В.Е., Лосева Н.Л. Энергетика ассимилирующей клетки и фотосинтез. Энергетические аспекты устойчивости растений. Казань: Изд-во Казан, ун-та, 1986. С. 5-76.

16. Tertyshnaya Yu.V., Levina N.S. The influence of the spectral composition of light on the development of crops. Agricultural machinery and technology. S. 24-29. [in Russian] / Тертышная Ю.В., Левина Н.С. Влияние спектрального состава света на развитие сельскохозяйственных культур. Сельскохозяйственные машины и технологии. С. 24-29. doi: 10.22314.2073-7599-2016.5. 
17. Chayka M.T., Savchenko G.E. Chlorophyll biosynthesis during the development of plastids. Minsk: Science and Technology, 1981. 168 р. [in Russian] / Чайка М.Т., Савченко Г.Е. Биосинтез хлорофилла в процессе развития пластид. Минск: Наука и техника, 1981. 168 с.

18. Yakushenkova T.P. Comparative effect of blue and red light on some physiological parameters and resistance of spring wheat seedlings. 2002. Author. diss. 21 p. [in Russian] / Якушенкова Т.П. Сравнительное влияние синего и красного света на некоторые физиологические показатели и резистентность проростков яровой пшеницы. 2002, Автореф. канд. дисс. 21 с.

\section{АЗІЗОВ І.В., ГАСІМОВА Ф.І., ІБРАГІМОВА У.Ф., ТАГІЄВА К.Р., АБДУЛЛАЄВА А.Б.}

Інститут молекулярної біологї та біотехнологій Національної Академії Наук Азербайджану,

Азербайджан, AZ1073, м. Баку, вул. Іззата Набієва, 11, e-mail: Ibrahim.azizov 47@ gmail.com, fazilay@yahoo.com

\section{ВПЛИВ СИНЬОГО І ЧЕРВОНОГО СВІТЛА НА ФІЗІОЛОГІЧНІ І БІОХІМІЧНІ ХАРАКТЕРИСТИКИ РОСЛИН ПШЕНИЦІ}

Mema. Досліджено вплив синього і червоного світла на активність пероксидази, каталази і аскорбату, вміст білків і розчинних вуглеводів у листках сортів пшениці під дією хлориду натрію. Методи. Об'єктами дослідження були сорт м'якої пшениці Саратовська-29 (Triticum aestivum L.) і твердої пшениці Баракатлі-95 (Triticum durum Desf.). Рослини вирощені в лабораторних умовах у рідкому живильному середовищі Кнопа. Експериментальні рослини вирощували під прозорими плівками, що пропускають світло на довжинах хвиль 420-480 нм (синє світло) і 640-680 нм (червоне світло). Протягом вегетаційного періоду, щотижня об 11:00, зразки повністю сформованих листків брали для фізіологічних і біохімічних досліджень. Результати. Під дією хлориду натрію накопичення перекису водню в білому світлі було вище, ніж в синьому і червоному. Низька активність каталази спостерігалася за впливу синього і червоного світла під дією хлориду натрію в обох сортах. У сорту хлібної пшениці Саратовська-29 рівень перекису водню і активність ферментів каталази та аскорбату пероксидази був нижчим, ніж у сорту пшениці Barakatli-95. Висновки. Синє світло стимулювало синтез білків, тоді як червоне світло стимулювало синтез вуглеводів. Сине і червоне світло перешкоджали утворенню $\mathrm{H}_{2} \mathrm{O}_{2}$ під дією $\mathrm{NaCl}$.

Ключові слова: синє світло, червоне світло, каталаза, аскорбат пероксидаза, білки, вуглеводи. 